\title{
Discrepancy between self-reported and observed hand hygiene behavior in nurses and physicians
}

\author{
T Watanabe \\ From International Conference on Prevention \& Infection Control (ICPIC 2011) \\ Geneva, Switzerland. 29 June - 2 July 2011
}

\section{Introduction / objectives}

The most effective method to promote health care workers' $\hat{A}$ Hand Hygiene $(\mathrm{HH}) \hat{\mathrm{A}}$ is observation and combined with an investigation of perceptions concerning $\mathrm{HH}$ further increases effectiveness.

\section{Methods}

Data were collected at a university hospital in Japan. Nurses and physicians' perceptions regarding their own $\mathrm{HH}$ adherence were measured using an anonymous questionnaire based on the World Health Organization's (WHO) "Five Moments for Hand Hygiene." The respondents were asked about their $\mathrm{HH}$ adherence in each of the five situations, and the responses were made using a 5 -point scale $(0 \%, 25 \%, 50 \%, 75 \%$, and $100 \%)$. For the analysis, these data were converted into points $(0,1,2$, 3 , and 4, respectively).Â Observations were performed in 17 ordinal wards and 4 intensive care units.

\section{Results}

A total of 137 questionnaires were returned from 126 nurses and 11 physicians. The nurses' mean selfreported $\mathrm{HH}$ adherence scores for 1) before touching a patient, 2)after touching a patient, 3) after touching a patient's surroundings, 4) before an aseptic/clean procedure, and 5) after a risk of body fluid exposure were $2.59,3.02,2.25,3.63$, and 3.72 , respectively, while the physicians' mean scores were $3.27,3.45,2.64,3.91$, and 3.91, respectively. The observed nurses' adherences were $62.0 \%, 72.8 \%, 43.0 \%, 70.8 \%$, and $87.4 \%$, respectively, while the physicians' adherences were $25.4 \%, 52.8 \%$, $42.9 \%, 34.8 \%$, and $96.5 \%$, respectively.Â Seventy-three percent of the $\mathrm{HH}$ failures among physicians before the

Department of Infection Control, Okayama University Hospital, Okayama, Japan performance of an aseptic/clean procedure were due to glove use.

\section{Conclusion}

The self-reported $\mathrm{HH}$ adherence and the observed $\mathrm{HH}$ adherence were measured for nurses and physicians. $\hat{A}$ The observed adherence before an aseptic/clean procedure was lower than the self-reported adherence, especially among physicians. This was due to glove use.

\section{Disclosure of interest}

None declared.

Published: 29 June 2011

doi:10.1186/1753-6561-5-S6-P120

Cite this article as: Watanabe: Discrepancy between self-reported and observed hand hygiene behavior in nurses and physicians. BMC

Proceedings 2011 5(Suppl 6):P120.

Submit your next manuscript to BioMed Central and take full advantage of:

- Convenient online submission

- Thorough peer review

- No space constraints or color figure charges

- Immediate publication on acceptance

- Inclusion in PubMed, CAS, Scopus and Google Scholar

- Research which is freely available for redistribution 